\title{
Seasonality of reproduction of epiphytic bryophytes in flooded forests from the Caxiuanã National Forest, Eastern Amazon
}

\author{
GABRIELA R. CERQUEIRA ${ }^{1}$, ANNA LUIZA ILKIU-BORGES ${ }^{2}$ and LEANDRO V. FERREIRA ${ }^{2}$ \\ ${ }^{1}$ Progama de Pós-Graduação em Botânica Tropical, Museu Paraense Emílio Goeldi/ \\ MPEG, Av. Perimetral, 1901, Terra Firme, 66077-830 Belém, PA, Brasil \\ ${ }^{2}$ Coordenação de Botânica, Museu Paraense Emílio Goeldi/MPEG, Av. \\ Perimetral, 1901, Terra Firme, 66077-830 Belém, PA, Brasil
}

Manuscript received on May 14, 2015; accepted for publication on July 22, 2015

\begin{abstract}
This work aimed to recognize the reproductive biology of the epiphytic bryoflora of phorophytes of Virola surinamensis (Rol. ex. Rottb.) Warb. in várzea and igapó forests in the Caxiuanã National Forest, to answer the following question: The reproductive period of the bryophyte species is influenced by the environment due the climatic seasonality present in flooded forests, being higher the occurrence of the sexual and asexual reproduction in the rainiest months? The bryophytes were identified and analyzed for the type of reproduction, sexual system and reproductive structures. In total, 502 samples of bryophytes were analyzed, resulting in 54 species, of which 34 were fertile. The comparison of the fertility of the species in different environmental conditions (dry or rainy, and igapó or várzea forest) was assessed using the chi-square test. The fertility of the seven studied species could not be defined by a pattern, considering the forest type and the seasonality. However, two species were associated to the forest type and two further species to the seasonality, showing that, for some bryophyte species, invest in constant fertility may be favoring the maintenance of their populations in tropical forests.
\end{abstract}

Key words: Amazon, bryoflora, fertility, Igapó forest, Várzea forest.

\section{INTRODUCTION}

The studies on the reproductive periods of plants are crucial to understand the success of the populations, since these events will ensure the survival and the establishment of young individuals (Ferraz et al. 1999). It is believed that the organisms can increase their ability, maximizing fecundity rates and enlarging their survival chances in different environments, and for this, life strategies

Correspondence to: Gabriela Ramos Cerqueira

E-mail: gabiibio@gmail.com and adaptations need to be developed in specific environmental contexts (Hedderson and Longton 1996).

The relation between the growth events through a time period and the reproduction in the life cycle of a species is the study object of the phenology (Rathcke and Lacey 1985). The seasonality of these events and the existence of different phases characterize the phenological studies (Rathcke and Lacey 1985, Stark 2002, Glime 2007). The understanding of these phases is critical to interpret the aspects of the reproductive ecology, as well 
as the characteristics related to the production of spores and propagules, and the longevity of individuals of a species (During 1979, Stark 2002).

The bryophytes have different strategies for their reproduction and the studies on this subject have risen through the last decades (Lloret Maya 1987, Oliveira and Pôrto 1998, 2001, LaakaLindberg 2005, Maciel-Silva and Válio 2011, Maciel-Silva et al. 2013). The reproduction of bryophytes can be sexual (gametophytic and sporophytic phase) or asexual (with production from the gametophyte, gemmae, propagules, and other structures) (Vanderpoorten and Goffinet 2009). Although both types of reproduction can be expressed in a species, there are those, especially the dioicous, which are limited to reproducing asexually (Frey and Kürschner 2011).

The species do not share the same strategy for reproduction, since the patterns of maturation of the reproductive structures respond to different periods and environmental conditions (Glime 2007). The studies on the bryoflora from temperate and Arctic regions indicate that some bryophytes remain dormant during the winter, while others use this time to reproduce (Glime 2007). In the tropics, the studies demonstrate that, even with the absence of a cold season, the presence of environmental factors such as precipitation, may cause effects on the sexual expression of some species (Glime 2007, Maciel-Silva and Válio 2011). Studies in tropical regions demonstrated the adaptation of the reproductive phenophases of bryophytes species evidencing a seasonal alternation between rainy and dry seasons (Egunyomi 1979, Makinde and Odu 1994, Oliveira and Pôrto 2001, 2002).

In Brazil, the works performed on the reproductive biology of bryophytes are concentrated in the Atlantic Forest biome (Oliveira and Pôrto 1998, 2001, Pôrto and Oliveira 2002, Maciel-Silva and Válio 2011, Maciel-Silva et al. 2012, 2013). The reproductive behavior parameters of bryophytes in two different habitats of dense ombrophilous forest, in the Atlantic Forest were investigated by Maciel-Silva et al. (2013). The latter authors found a continuous sexual expression over the period of study, but with evidence of some differences in the maturation of the gametangia and production of sporophytes. The knowledge of these parameters to other biomes and forest formations are still unknown, such as in the Amazon. Because of its remarkable seasonality, it is expected that the production of sexual branches, sporophytes and asexual structures also alternate between periods of high and low rainfall in the Amazon, since bryophytes depends on moisture for reproduction (Glime 2007).

Among the various forest types represented in the Amazon, known for its remarkable species richness and high endemism level (Mittermeier et al. 1992), including bryophytes (Gradstein et al. 2001, Gradstein and Costa 2003), stand out the floodable forests, represented mainly by várzea and igapó. These two forest types differ by being, respectively, periodical and permanently flooded, besides presenting contrasting quantities of sediments and organic material, as well as, having different geological origin (Melack and Hess 2010, Junk et al. 2011). One of the factors that contribute to the configuration of these forests is the characteristic rainfall of the Amazon biome (Souza et al. 2009, Wittmann et al. 2006).

To formulate the question of the present study we considered the effects of the rainfall, which contribute to the success of the sexual reproductive cycle in bryophytes, favor the self-fertilization and the formation of the sporophytes, as well as provide moisture to the development of the asexual diaspores. Additionally, we considered the results of works carried out in other tropical forests, which demonstrated that the sexual expression of the bryophytes responds to seasonality. Therefore, the present study aimed to recognize the seasonality of reproduction of the epiphytic bryoflora of phorophytes of Virola surinamensis (Rol. ex. 
Rottb.) Warb. in várzea and igapó forests in the Caxiuanã National Forest, to answer the following question: The reproduction period of the bryophyte species is influenced by the environment due to the sazonality in the flooded forests? Thus, the sexual and assexual reproduction is favored in months with higher rainfall?

\section{MATERIALS AND METHODS}

The botanical material was collected in flooded forests in the Caxiuanã National Forest, located in the interfluve between Xingu and Tocantins rivers, in the municipalities of Portel and Melgaço $\left(01^{\circ}\right.$ 42' 30" S, 51 31' 45" W; 62 m elevation), in Pará State, Brazil. The climate of the region, according to the Köppen classification, is tropical monsoon climate "Am" and climate subtype with a short dry season (Oliveira et al. 2008). The average annual temperature is $25.7 \pm 0.8^{\circ} \mathrm{C}$ and the average annual relative humidity is $82.3 \%$ (Oliveira et al. 2008). Rainfall in FLONA Caxiuanã between the months of July 2013 and June 2014 ranged from 65.3 $\mathrm{mm}$ to 324.11 , respectively (A.C.L. Costa et al., unpublished data).

The vegetation of the Caxiuanã National Forest consists of dense ombrophilous forests (mainland forests - 85\%); alluvial dense ombrophilous forests (igapó and várzea forests - 10\%); enclaves of meadow and savanna vegetations, and spots of secondary vegetation (Almeida et al. 2003).

The várzea forests in Caxiuanã National Forest are seasonally flooded due to annual and daily tidal fluctuation by small igarapés and especially by the Caxiuanã bay. This forest has open canopy and the underforest presents species of the arboreous component in natural regeneration (Ferreira et al. 2013). Those are forests flooded by rivers with higher bulk of sediments and the soils are classified as Plinthosols, poorly drained and with a higher proportion of nutrients (Piccini and Ruivo 2012).

The igapó forests are seasonally flooded due to annual fluctuation of the rivers and streams of black water and also by daily tidal flooding. It has the most closed canopy and dense vegetation in the underforest, characterized by species of Araceae, Cyperaceae and Rapateaceae (Ferreira et al. 2013, C.C.S. Souza et al., unpublished data). The soils are classified as Gleysols, with conditions of poor drainage and nutrients and high fragility (Piccini and Ruivo 2012).

The collections of bryophytes were performed in the várzea and igapó forests, within the plots of the Programa de Pesquisas Ecológicas de Longa Duração (two plots of $100 \times 100 \mathrm{~m}$ in each forest) and surrounding areas. The Virola surinamensis phorophyte was chosen due to its high density of individuals in both forests (Ferreira et al. 2005), and in order to avoid variations if more than one phorophyte was chosen and to ensure the replicas of the sample units.

The excursions to carry out the collections occurred in July, September and November 2013 (period of lowest precipitation - dry) and February, April and June 2014 (period of higher precipitation - rain), totaling six excursions. We collected 255 samples of bryophytes in the várzea and 247 in the igapó forest.

The botanical samples were taken on the trunks of the trees, in a standardized way, using the dimensions of $20 \times 20 \mathrm{~cm}$, as suggested by Frahm (2003), measured with a mold made of Styrofoam material. The method for the collection is according to that proposed by Lisboa (1993). Only phorophytes with diameter at breast height (DBH) above $20 \mathrm{~cm}$ were chosen for sampling, which was always held at a height of $1.30 \mathrm{~m}$ from the ground, face to the east side.

The specimens were identified with the aid of taxonomic keys elaborated by Griffin III (1979), Lisboa (1993), Ireland and Buck (1994), Gradstein et al. (2001), Lemos-Michel (2001), Gradstein and Costa (2003), Gradstein and Ilkiu-Borges (2009), Ilkiu-Borges and Lisboa (2000, 2002, 2004), and was incorporated in the herbarium MG. 
During the identification, it was observed the presence of reproductive structures (sexual or assexual) on the specimens. The fertility term, as adopted in the present paper, indicates the presence of any structure developed to forming another plant. We observed how was the type of reproduction (sexual or asexual), what was the sexual system (monoicous or dioicous), and what structures were produced in both types of reproduction. From the sexual reproduction was noted the presence of male and female sexual branches and open or closed sporophytes. From the asexual reproduction was noted the presence of the following structures: gemmae, propagules, and caducous leaves. The sexual systems were defined based on the identified material and data available in the literature.

We compared the occurrence of fertile individuals of each species of bryophytes in different environmental conditions, dry or rain and igapó or várzea forest, using the chi-square test. This test is appropriate to compare the relation between two binary variables, giving an indication of the correlation between two of these conditions (Zar 2010).

The chi-square test was performed at the species level. Due to power constraints of the statistical test and its presuppositions, we analyzed only species with a number of occurrences equal to or greater than 20 and that had cases of fertility in the two environments or stations. The species that did not meet these requirements were evaluated descriptively.

\section{RESULTS AND DISCUSSION}

We analyzed 502 samples of bryophytes and found 54 species, distributed in 13 families. Of the 54 identified species, 34 were fertile (Table SI Supplementary Material). Of these, 17 were fertile in both forests, seven only in várzea and 10 only in the igapó forest, totaling 24 fertile species in várzea and 27 in the igapó forest. During the dry and rainy period were recorded 29 and 30 fertile species, respectively.

The species presenting fertility in only one of those environments obtained low number of occurrences or were recorded in only one of the forests, for example: Cheilolejeunea comans (Spruce) R.M. Schust., Lejeunea adpressa Nees and Mastigolejeunea auriculata (Wilson) Schiffn. in várzea forest, and Leucomium strumosum (Hornsch.) Mitt., Fissidens guianensis Mont. and Fissidens prionodes Mont. in igapó forest.

Only seven species fulfilled the prerequisites to be analyzed for fertility, with which was held the chi-square test (Table II). Two species, Calymperes lonchophyllum and Ceratolejeunea cubensis, presented a higher occurrence of fertile plants in the rainy period. Thus, the hypothesis that the period

TABLE II

Result of the chi-square test for the fertility of the species in both forests (várzea and igapó) and in both periods (dry and rainy). *Significant at $\mathrm{p}<0.05$ level. **Significant at $\mathrm{p}<0.001$ level. Degree of freedom $=1 . \mathrm{N}=$ Number of samples. $\chi 2=$ test result chi-square.

\begin{tabular}{lccccc}
\hline & & \multicolumn{2}{c}{ Season } & \multicolumn{2}{c}{ Environment } \\
\cline { 3 - 6 } \multicolumn{1}{c}{ Species } & $\mathbf{N}$ & $\chi \mathbf{2}$ & Pattern & $\chi \mathbf{2}$ & Pattern \\
\hline Calymperes erosum & 98 & 2.13 & - & $14.63^{* *}$ & Igapó \\
\hline C. lonchophyllum & 261 & $22.57^{* *}$ & Rain & 0.49 & - \\
\hline Ceratolejeunea cubensis & 374 & $11.56^{* *}$ & Rain & $5.15^{*}$ & Igapó \\
\hline Lejeunea cerina & 122 & 2.11 & - & 3.04 & - \\
\hline Radula javanica & 229 & 2.41 & - & $7.52^{* *}$ & Várzea \\
\hline Symbiezidium barbiflorum & 113 & 0.31 & - & 0.25 & - \\
\hline Symbiezidium sp. & 110 & 1.5 & - & 2.5 & - \\
\hline
\end{tabular}


favored the sexual expression of bryophytes was confirmed only for these two species. Besides the constant humidity in the two studied forest types, which are flood forest in a region where even in the dryer periods there are rain, it is believe that the functional characters and the own natural history of the species may have contributed for this result. Still, such parameters where not analyzed in the present paper. A similar result was found for Calymperes erosum and Radula javanica concerning their fertility in relation to the forest type.

The other studied species presented fertility constant, independent of the period and/or the forest type, which indicates an opportunist strategy adopted by some species in tropical forest, as those environments possess warm temperatures and high water availability, providing that these plants produce constantly sexual structures (Oliveira and Pôrto 1998, Pôrto and Oliveira 2002, Maciel-Silva and Válio 2011).

Similar results, concerning the constant sexual expression, were obtained by a monitoring of bryophytes for 15 months in two forests in the Atlantic Forest (at sea level with periodic flooding and in a mountain forest with constant presence of fog) (Maciel-Silva and Válio 2011).

The sexual reproduction was the most frequent type of reproduction, observed in 25 species (Figure 1 ), while four species presented reproduction by means of caducous leaves and propagules. Five species presented both forms of reproduction.

The sexual reproduction allows the exchange of genetic material, offering the possibility of genetic variation forming different genotypes, stimulating the evolution by favoring, for example, adaptations to changing ecological conditions (Frey and Kürschner 2011). The asexual reproduction, while not contributing to genetic variation, has great importance for the maintenance of regional populations, in the colonization and maintenance of the habitats by the bryophytes (Frey and Kürschner 2011)

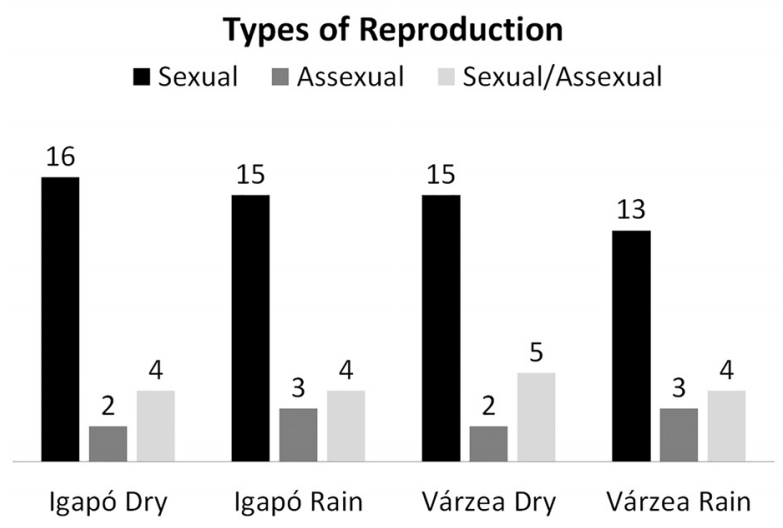

Figure 1 - Number of species and forms of reproduction of bryophytes in the forests of várzea and igapó in periods of drought and rain.

The dioecious and monoecious were frequent occurring in 17 and 15 species respectively, while two species presented both sexual systems (Table SI). Both monoecious and dioecious liverworts were often found with perianth and androecia, which may represent a balance between the male and female colonies and promote the maintenance of the epiphytic liverwort populations in the studied forests. Regarding the mosses, were observed 10 sporophytes, distributed in four species: two monoicous acrocarpous (Fissidens guianensis with five sporophytes and $F$. prionodes with just one) and two monoicous pleurocarpous (Leucomium strumosum and Pilotrichum bipinnatum with two sporophytes each). The monoicous mosses are often found with higher production rates of sporophytes than the dioicous and it is believed that the proximity between the gametangia on the branches of monoicous species facilitates, independent of the habitat, the fecundation and subsequent growth of the sporophytes (Longton and Schuster 1983, Oliveira and Pôrto 1998). In the monoicous species, although the self-fertilization prevents genetic exchange, it ends up being a way to guarantee that sexual reproduction occurs (Longton and Schuster 1983, Oliveira and Pôrto 1998).

Among mosses, in general, the dioicous condition is considered as being primitive, however, 
dioicous bryophytes may have difficulties that prevent the fertilization, because of the distance that can exist between the male and female populations, associated with the problem of the maturation not always synchronic of the gametangia (Longton and Schuster 1983, Bowker et al. 2000, Oliveira and Pôrto 2002, Stark et al. 2005, 2010). The probability of fertilization in dioicous acrocarpous mosses are low, due to a single unisexual branch being produced at the apex of the branches per growth period (La Farge 1996).

The information helps in the understanding of two most common acrocarpous mosses found in the study area (Calymperes erosum and $C$. lonchophyllum). The two species were reproducing exclusively asexually through propagules at the leaf apex (propaguliferous leaves), since both are dioicous (Oliveira and Pôrto 1998) and sporophytes were not observed. Among the Calymperaceae species, the sexual reproduction and the formation of sporophytes are rare conditions (Sharp et al. 1994), so that, as obtained in this study and already reported in the literature, asexual structures are developed to ensure the production of new gametophytes. The majority of moss species is capable of undergoing the asexual reproduction of the gametophytes, which will produce specialized vegetative diaspore or will do this by regeneration from gametophyte fragments (Hedderson and Longton 1996).

The five species with both types of reproduction are all liverworts (Lejeunea tapajosensis, Lepidolejeunea involuta, Rectolejeunea berteroana, Radula javanica and Plagiochila montagnei). Among the liverworts this behavior allows quick occupation of the substrates, particularly on epiphytes, since the presence of numerous gemmae enable the species to spread vegetatively and establish on the vertical substrates, increasing their survival chances (Glime 2007, Bastos 2008). It is believed that the vegetative reproduction processes are a safe strategy for the production of new individuals, considering the difficulties that may prevent the sexual process (Laaka-Lindberg 2000). In addition, the asexual diaspores provide possibilities of survival face the unfavorable environmental conditions, as well as assist the reestablishment of the bryophytes in a habitat after changing of the environmental conditions (Frey and Kürschner 2011).

\section{ACKNOWLEDGMENTS}

The authors are grateful to the Programa de Pesquisas Ecológicas de Longa Duração (PELDCaxiuanã) for financial support to the fieldwork, to the Ferreira Penna Scientific Research Station for logistical and human support during the collections, to the Coordenação de Aperfeiçoamento de Pessoal de Nível Superior (CAPES) for granting the scholarship to the first author, and to the Conselho Nacional de Desenvolvimento Científico e Tecnológico (CNPq) for the productivity grant for the second and third authors.

\section{RESUMO}

Este trabalho teve como objetivo conhecer a biologia reprodutiva da brioflora epífita de forófitos de Virola surinamensis (Rol. ex. Rottb.) Warb. na várzea e igapó na Floresta Nacional de Caxiuanã, para responder à seguinte pergunta: O período de reprodução das espécies de briófitas é influenciado pelo ambiente devido a sazonalidade climática presente em florestas inundadas, sendo maior a ocorrência da reprodução sexuada e assexuada nos meses mais chuvosos? As briófitas foram identificadas e analisadas quanto ao tipo de reprodução, sistema sexual e estruturas reprodutivas. No total, foram analisadas 502 amostras de briófitas, resultando em 54 espécies, das quais 34 eram férteis. A comparação da fertilidade das espécies em diferentes condições ambientais (seca ou chuva e igapó ou várzea) foi avaliada pelo teste do qui-quadrado. A fertilidade das sete espécies testadas não pode ser definida por um padrão, com relação aos tipos de florestas e aos períodos. Entretanto, duas espécies foram associadas ao período com chuvas e outras duas espécies ao tipo de floresta, 
o que revela que, para algumas espécies de briófitas, investir na fertilidade constante pode estar favorecendo a manutenção das suas populações em florestas tropicais.

Palavras-chave: Amazônia, brioflora, fertilidade, Floresta de Igapó, Floresta de Várzea.

\section{REFERENCES}

ALMEIDA SS, AMARAL DD AND SILVA ASL. 2003. Inventário Florístico e Análise Fitossociológica dos Ambientes do Parque de Gumna, município de Santa Bárbara, Belém, Pará. Relatório Técnico MPEG/JICA, 185 p.

BAstos CJP. 2008. Padrões de reprodução vegetativa em espécies de Lejeuneaceae (Marchantiophyta) e seu significado taxonômico e ecológico. Rev Bras Bot 31(2): 309-315.

BOWKER MA, STARK LR, MCLETCHIE DN AND MISHLER BD. 2000. Sex expression, skewed sex ratios, and microhabitat distribution in the dioecious desert moss Syntrichia caninervis (Pottiaceae). Am J Bot 87(4): 517-526.

DURING HJ. 1979. Life strategies of bryophytes: a preliminary review. Lindbergia 5(1): 2-18.

EGUNYOMI A. 1979. Autoecology of Octoblepharum albidum Hedw. in Western Nigeria 11. Phenology and water relations. Nova Hedwigia 31(1): 377-387.

FERRAZ DK, ARTES R, MANTOVANI W AND MAGALHIES LM. 1999. Fenologia de Árvores em Fragmento de Mata em São Paulo (SP). Rev Bras Biol 59(2): 305-317.

FERREIRA LV, ALMEIDA SS, AMARAL DD AND PAROLIN P. 2005. Riqueza e Composição de Espécies da Floresta de Igapó e Várzea da Estação Científica Ferreira Penna: Subsídios para o Plano de Manejo da Floresta Nacional de Caxiuanã. Botânica 56: 103-116.

FERREIRA LV, CHAVES PP, CUNHA DA, MATOS DCL AND PAROLIN P. 2013. Variação da Riqueza e Composição de Espécies da Comunidade de Plantas entre as florestas de Igapós e Várzeas na Estação Científica Ferreira PennaCaxiuanã na Amazônia Oriental. Botânica 64: 175-195.

FRAHM JP. 2003. Manual of Tropical Bryology. Trop Bryol 23: 9-195.

FREY W AND KÜRSCHNER H. 2011. Asexual reproduction, habitat colonization and habitat maintenance in bryophytes. Flora 206(3): 173-184.

GLIME JM. 2007. Bryophyte Ecology. Volume 1. Physiological Ecology. Ebook sponsored by Michigan Technological University and the International Association of Bryologists. Retrieved November 14, 2014. http://www.bryoecol.mtu. edu.

GRADSTEIN SR, CHURCHILL SP AND SALAZAR-ALLEN N. 2001. Guide to the bryophytes of tropical America (Memoirs of the New York Botanical Garden, 86) The New York Botanical Garden Press. New York, 577 p.
GRADSTEIN SR AND COSTA DP. 2003. The Hepaticae and Anthocerotae of Brazil (Memoirs of the New York Botanical Garden 87). Memoirs of the New York Botanical Garden Press. New York, 336 p.

GRADSTEIN SR AND ILKIU-BORGES AL. 2009. Guide to the Plants of Central French Guiana. Part 4. Liverworts and Hornworts. Memoirs of the New York Botanical Garden Press. New York, $140 \mathrm{p}$.

GRIFFIN III D. 1979. Guia Preliminar para as Briófitas frequentes em Manaus e adjacências. Acta Amaz 9(3): $1-67$.

HEDDERSON TA AND LONGTON RE. 1996. Life history variation in mosses: water relations, size and phylogeny. Oikos 77(1): 31-43.

ILKIU-BORGES AL AND LISBOA RCL. 2000. Os gêneros Leptolejeunea e Raphidolejeunea (Lejeuneaceae) na Estação Científica Ferreira Penna, Pará, Brasil. Acta Amaz 32(2): 205-215.

ILKIU-BORGES AL AND LisBOA RCL. 2002. Os gêneros Lejeunea e Microlejeunea (Lejeuneaceae) na Estação Científica Ferreira Penna, Estado do Pará, Brasil, e novas ocorrências. Acta Amaz 32(4): 541-553.

ILKIU-BORGES ALAND LISBOA RCL. 2004. Os gêneros Cyclolejeunea, Haplolejeunea, Harpalejeunea, Lepidolejeunea e Rectolejeunea (Lejeuneaceae, Hepaticae) na Estação Científica Ferreira Penna, Pará, Brasil. Acta Bot Bras 18(3): 537-553.

IRELAND RR AND BUCK WR. 1994. Stereophyllaceae. Flora Neotropica Monograph N. 65. New York Botanical Garden Press. New York, 50 p.

JUNK WJ, PIEDADE MTF, SCHÖNGART J, COHN-HAFT M, ADENEY MJ AND WITTMANN F. 2011. A Classification of Major Naturally-Occurring Amazonian Lowland Wetlands. Wetlands 3(4): 623-640.

LA FARGE C. 1996. Growth Form, Branching Pattern, and Perichaetial Position in Mosses: Cladocarpy and Pleurocarpy Redefined. Bryologist 99(2): 170-186.

LAAKA-LINDBERG S. 2000. Substrate preference and reproduction in Lophozia silvicola (Hepaticopsida) in southern Finland. Ann Bot Fenn 37(2): 85-93.

LAAKA-LINDBERG S. 2005. Reproductive phenology in the leafy hepatic Lophozia silvicola Buch in southern Finland J Bryol 27(3): 253-259.

LEMOS-MiCHEL E. 2001. Hepáticas epifíticas sobre o pinheirobrasileiro no Rio Grande do Sul. Ed. Universidade Federal do Rio Grande do Sul. Porto Alegre, 191 p.

LISBOA RCL. 1993. Musgos Acrocárpicos do Estado de Rondônia. Mus Para Emílio Goeldi. Belém, 272 p.

LLORET-MAYA F. 1987. Efecto de la altitud sobre la fenología de briófitos en el Pirineo oriental. An Jard Bot Madr 43(2): 203-215.

LONGTON RE AND SCHUSTER RM. 1983. Reproductive biology. In: New Manual of Bryology Schuster RM (Ed), Hattori Botanical Laboratory, Nichinan, p. 386-462. 
MACIEL-Silva AS, COELHO MLP AND PÔRTO KC. 2013. Reproductive traits in the tropical moss Octoblepharum albidum Hedw. differ between rainforest and coastal sites. J Bryol 35(3): 206-215.

MACIEL-SILVA AS AND VÁLIO IFM. 2011. Reproductive phenology of bryophytes in tropical rain forests: the sexes never sleep. Bryologist 114: 708-719.

MACIEL-SILVA AS, VÁLIO IFM AND RYDIN H. 2012. Altitude affects the reproductive performance in monoicous and dioicous bryophytes: examples from a Brazilian Atlantic rainforest. AoB Plants 2012: 1-14.

MAKINDE AM AND ODU EA. 1994. Phenological studies of selected savanna mosses of south-western Nigeria. Experientia 50(6): 616-619.

MELACK JM AND HeSS LL. 2010. Remote Sensing of the distribution and extent of wetlands in the Amazon Basin. In: Amazonian Floodplain Forests: Ecophysiology, Biodiversity and Sustainable Management. Junk WJ, Piedade MTF, Wittmann F, Schöngart J and Parolin P (Eds), Ecol. Stud. Springer Verlag Dordrecht-HeidelbergLondon-New York, p. 44-58.

MITTERMEIER RA, WERNER T, AYRES JM AND FONSECA GAB. 1992. O país da megadiversidade. Cienc Hoje 14(81): 20-27.

Oliveira LL, COSTA RF, SOUSA FAS, COSTA ACL AND BRAGA AP. 2008. Precipitação efetiva e interceptação em Caxiuanã, na Amazônia Oriental. Acta Amaz 38(4): 723732.

OLIVEIRA SM AND PÔRTO KC. 1998. Reprodução sexuada em musgos acrocárpicos do Estado de Pernambuco, Brasil. Acta Bot Bras 12(3): 385-392.

OLIVEIRA SM AND PÔRTO KC. 2001. Reproductive phenology of the moss Sematophyllum subpinnatum in a tropical lowland forest of north-eastern Brazil. J Bryol 23(1): 1721.

OliveIRA SM AND PÔRTO KC. 2002. Population Profile of Bryum apiculatum Schwaegr. in an Atlantic Forest Remnant, Pernambuco, Brazil. J Bryol 24: 251-258.

PICCININ J AND RUIVO ML. 2012. Os solos da Floresta Nacional de Caxiuanã. In: Plano de Manejo da Floresta
Nacional de Caxiuanã - ICMBIO: Instituto Chico Mendes de Conservação da Biodiversidade, p. 120-127.

PÔRTO KC AND OLIVEIRA SM. 2002. Reproductive phenology of Octoblepharum albidum (Bryopsida, Leucobryaceae) in a tropical lowland forest of north-eastern Brazil. J Bryol 24(4): 291-294.

RATHCKE B AND LACEY EP. 1985. Phenological patterns of terrestrial plants. Annu Rev Ecol Syst 16: 179-214.

SHARP AJ, CRUM H AND ECKEL PM. 1994. The moss flora of Mexico. Mem N Y Bot Gard 69(1-2): 1-1113.

SouZA EB ET AL. 2009. Precipitação sazonal sobre a Amazônia oriental no período chuvoso: observações e simulações regionais com o RegCM3. Rev Bras Meteorol 24(2): 111-124.

STARK LR. 2002. Phenology and its repercussions on the reproductive ecology of mosses. Bryologist 105(2): 204218.

STARK LR, MCLETCHIE DN AND EPPLEY SM. 2010. Sex ratios and the shy male hypothesis in the moss Bryum argenteum (Bryaceae). Bryologist 113(4): 788-797.

STARK LR, MCLETCHIE DN AND MISHLER BD. 2005. Sex expression, plant size, and spatial segregation of the sexes across a stress gradient in the desert moss Syntrichia caninervis. Bryologist 108(2): 183-193.

VANDERPOORTEN A AND GOFFINET B. 2009. Introduction to Bryophytes. Cambridge, Cambridge University Press, $328 \mathrm{p}$.

WitTMANN F, SCHÖNGART J, MONTERO JC, MOTZER T, JUNK WJ, PIEDADE MTF, QUEIROZ HL AND WORBES M. 2006. Tree species composition and diversity gradients in white-water forest across the Amazon basis. J Biogeogr 33: 1334-1347.

ZAR JH. 2010. Biostatistical Analysis. $5^{\text {th }}$ ed., Pearson PrenticeHall, Upper Saddle River, New Jersey, 944 p.

\section{SUPPLEMENTARY MATERIAL}

TABLE SI - Species and sexual systems of fertile bryophytes at igapó and várzea forests during the periods of lower and higher precipitation (dry and rain). $D=d r y ; R=$ rain; $V=$ Várzea $\mathbf{I}=$ Igapó $; \mathrm{X}=$ presence of reproductive structures. 